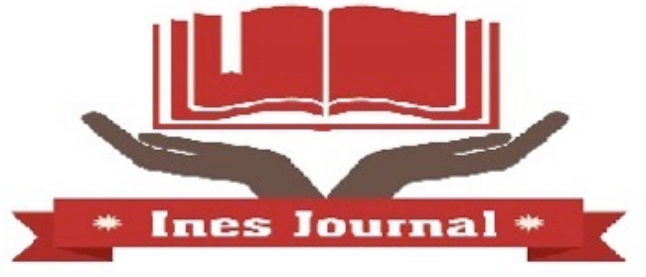

Yıl: 2, Sayı: 5, Aralık 2015, s. 449-457

\section{INESJOURNAL}

ULUSLARARASI EĞİTIMM BİLİMLERİ DERGİSİ THE JOURNAL OF INTERNATIONAL EDUCATION SCIENCE

\author{
Hülya YARDIMCI ${ }^{1}$, Fatma Özgün ÖRMECİ ${ }^{2}$, Ayșe Özfer ÖZÇELİK ${ }^{3}$, \\ Metin Saip SÜRÜCÜOĞLU ${ }^{4}$, Yahya ÖZDOĞAN ${ }^{5}$
}

\title{
NUTRITION EDUCATION IN PRESCHOOL CHILDREN
}

\begin{abstract}
Nutrition education plays a vital role in bringing about a greater awareness of the value nutrition has in adopting a healthy lifestyle. Broadly speaking, education is transformative, providing knowledge through instruction that first acts upon the attitudes of a person and then goes on to influence their behavior. The earlier this process begins, the more effective it is. That is why the provision of training as early as the pre-school years can be viewed as a future investment, considering that the healthy eating habits are formed at early ages. The aim of nutrition education, therefore, is to instruct children on how to adopt an adequate and balanced diet, eliminate unhealthy eating habits, use food resources economically by improving nutritional conditions and preserve the well-being of the body. By providing children with nutrition education during the preschool period, their future eating habits can be shaped in a healthy manner.
\end{abstract}

Key words: Education, nutrition, preschool.

\section{INTRODUCTION}

The first six years of a child's life mark a period of rapid physical, emotional and mental development. During these formative years, they also interact with the social environment at the most intensive level (Aktaş et al., 2011). Early childhood development pertains to physical, mental and social growth and consists of various interventions, such as those involving the promotion of nutrition, health and mental and social development (Özmert, 2005).

\footnotetext{
${ }^{1}$ Dr., Ankara University, Faculty of Health Sciences Department of Nutrition and Dietetics, Ankara, Turkey, hulya_yardimci@yahoo.com

${ }^{2}$ Dr., Middle East Technical University, Medical Center, Department of Pediatrics, Ankara, Turkey, fzgn06@gmail.com

${ }^{3}$ Prof.Dr., Ankara University, Faculty of Health Sciences Department of Nutrition and Dietetics, Ankara, Turkey, ozferozcelik@gmail.com

${ }^{4}$ Prof.Dr., Mevlana University, Faculty of Health Sciences Department of Nutrition and Dietetics, Konya, Turkey, metinsaip@gmail.com

${ }^{5}$ Dr., Selcuk University, Faculty of Health Sciences Department of Nutrition and Dietetics, Konya, Turkey, yozdogan@selcuk.edu.tr
} 
From the first year on, a child starts to acquire a sense of independence with each passing day. As an individual who develops within a family, a child forms eating habits during this period of development and change that are directly or indirectly affected by the eating habits of the family; that is, the mother, father, brothers or sisters or caregiver (Anonymous, 2008). The preschool years are an great time to help children form positive attitudes towards food and develop good eating habits (Anonymous, 2004). Teaching children to make healthy choices in the food they select is certainly a worthwhile goal and one that will affect their lives through adulthood (Anonymous, 2000). Furthermore, during the preschool period inadequate and unbalanced nutrition negatively impacts the physical and mental development and learning ability of a child. This negative impact on children manifests itself as learning disabilities and failure in the period of preschool education (Anonymous, 2008).

Consumption of a healthy diet is essential for children to ensure that they undergo normal growth and development and to prevent a variety of nutrition-related health problems, such as anemia, growth retardation, malnutrition, compromised cognitive achievement, obesity, dental problems, and chronic diseases later in life (Stang et al., 1998 ; ADA, 2008). The importance of having proper nutrition has in recent years been emphasized as a key factor in leading a healthy life and has contributed to the trend toward healthier diets (Barzegari et. al., 2011).

As insufficient information about nutrition leads to many dietary-related health problems, it is necessary that persons of all ages be provided nutrition education to mitigate these risks. Adolescents are the most affected by the problems associated with insufficient and imbalanced nutrition. For this reason, it is very important that nutrition education be provided as early as possible, preferably during the preschool period. In addition to the family, schools should also be tasked with the responsibility of educating children on nutrition in order to create awareness in them about this issue. This will help children to not only improve their physical health but to also raise their levels of achievement at school.

In this respect, the most important mission of parents and particularly educators is to make the best use of the resources, teach students correct nutritional habits based on sound nutritional principles, correct wrong information and habits about nutrition and transform positive practices into a lifestyle (Şanlıer, 1999). For children, healthy eating is learned by actively observing and doing. In providing positive food experiences, early childhood programs help children to develop an awareness of good nutrition and to develop healthy eating habits for a lifetime (Davidson, 2012). It is of critical importance that nutrition education be given at early ages, particularly in the preschool period, to ensure that a healthy lifestyle is maintained. It has been well-established that nutrition education programs have a positive impact on nutritional knowledge and eating habits (Anonymous, 2004).

\section{Nutrition Education}

Education is transformative, providing knowledge through instruction that first acts upon the attitudes of a person and then goes on to influence their behavior. This process is made up of many steps, such as planning, organizing, application, repetition, checking and re-application (Merdol, 2012a). The healthy development of a person starts, before they are even born, with the health and nutrition of the mother, and is a process that continues throughout their life. The part of this process that begins at birth and lasts until the age of compulsory education is called 
the "preschool education period". This period is the most significant stage of human development, in terms of the impressionable affect the surrounding environment and events taking place within that environment have on the children. Accordingly, the preparation of environmental opportunities coupled with the exposure children are given to a variety of qualified stimulants will influence their mental and social development positively. The earlier the education starts, the more effective and lasting it is (Aygün, 1994).

The field of nutritional science involves determining and analyzing how the body uses food for energy and growth and investigating how the nutrients affect the body's ability to maintain its health and protect itself from chronic diseases (Baysal, 2014). Nutrition education involves teaching about the importance of nutrition, providing educational materials that reinforce the messages about healthy eating, teaching skills essential for making dietary changes and providing information on how to sustain behavioral change (Stang \&Story, 2005). Nutrition education, which is vital to the development of a healthy life style, is comprised of individual or group sessions. In these sessions, materials designed to improve health status by achieving a positive change in dietary habits and to highlight the relationships between nutrition and health, all in keeping with the individual's personal, cultural and socio-economic preferences, are provided (Ozcelik et al., 2008). Results have shown that through the provision of nutrition education, individuals can advance their nutritional knowledge and practices and thereby improve their nutritional status (Kilaru et al., 2005). Nutrition education therefore can play a major role in the way caregivers feed their children, which in turn can contribute to an overall improvement of the nutritional status of children (Mushaphi, 2011).

The preschool period is of vital importance in terms of behavioral development, both positive and negative. One of the most remarkable features exhibited by preschool-aged children is the difficulty they have in choosing their own food. To know this, it is important that the parents, and especially the educators, help them to acquire healthy nutritional habits that are in line with nutrition principles, correct their inaccurate understanding and wrong habits of nutrition and guide them in adopting positive nutritional behavior in daily life (Şanlıer, 1999).

Healthy eating habits that have been adopted in the preschool period affect the later periods in life, providing the basic solution to preventing nutrition problems that might emerge in the future, as nutrition affects a child's physical, social and emotional development as well as their behavior (Ünver \&Ünüsan, 2005). Caregivers should involve older children in helping to prepare food and in setting and clearing tables. Moreover, as the caregiver eats at the same time as the children, it is important that they set a good example and be a role model by following healthy eating guidelines, sitting down at the table to eat and promoting a positive attitude towards healthy food (Anonymous, 2004).

At preschool age, children begin to understand concepts like nutritive value, nutrient function and the impact of nutrition on health (Räsänen et al., 2001). The importance of teaching young children to make nutritious food choices is grounded in the connections between nutrition and learning, the development of personal choice that gradually begins to emerge in children and evidence showing that the diets of preschool children may not be optimal for forming a lifetime pattern (Plum, 1997). 


\section{H. YARDIMCI, F. Ö. ÖRMECI, A. Ö. ÖZÇELİK, M. S. SÜRÜCÜOĞLU, Y. ÖZDOĞAN}

Preschool is the perfect setting for educating children on the principles of good nutrition. A key factor in the success of preschool nutrition education programs is the use of developmentally appropriate learning experiences for children (Aktaş et al., 2011).

The nutrition education programs for children mainly include four sections. These sections are: Questions, Provision of information, Stories and Practice. The Questions section includes questions posed by the instructor to the students on the subject to be taught. These questions are presented with two specific purposes. The first purpose is to help students become familiar with the program and the second one is to determine the change in the students' level of understanding before and after the program. The education model must include the questions that have been answered correctly, as the information provided in the Provision of information section will be determined by making revisions according to these correct answers. The purpose of the Provision of information section is to teach students the basic information about nutrition. This section also includes information pertaining to the questions presented in the previous section, and employs figures and images prepared by the educator beforehand. In conducting this section, it is important that the children repeat the responses.

The third section of the nutrition education model involves the use of texts that are consistent with the message of the program. One of the most effective methods in teaching children is story telling. It helps children to better understand the message of the program. The illustrations accompanying the story can be prepared within the context of the program by the educators themselves or together with the children. The illustrations should be related to the content of stories and only a minimal number of illustrations should be used. The fourth section, the practice stage, should ideally begin right after the first, second and third sections are completed. However, depending on the unique set of circumstances governing the students, this section can also be performed at another time deemed more appropriate by the educator. The practice section may include painting activities conducted on different subject matter, role-playing a story that has been told beforehand or using cardboard or play dough to recreate stories. After implementation of the program, teachers, mothers or caregivers should monitor the behavior and attitudes of the children towards the educational program, and the information communicated by the children should be reinforced by asking relevant questions (Merdol, 2012a).

Nutrition education features three essential phases or components (Contento, 2008):

1. A motivational phase, where the goal is to increase awareness and enhance motivation of the intended audience. Here the focus is on why make changes.

2. An action phase, where the goal is to facilitate the ability to take action. The focus here is on how tomake changes.

3. An environmental component where nutrition educators work with policymakers and others to promote environmental supports for action. Each component needs to be based on appropriate theory and research.

It is important to be informed about the changes in children's cognitive development when planning the nutrition education in order to prepare a program consistent with their age. Nutrition education in early childhood should (Davidson, 2012):

* be age-appropriate, 
* be positive,

* be fun, interactive, and engaging,

* begin to teach children the relationship between food and health, as well as expose children to a variety of learning experiences about foods,

* help children start to develop sound attitudes and acquire accurate knowledge about food, nutrition, and health,

* be integrated into daily routines whenever possible, such as at mealtime and during transitions.

Successful nutrition education programs influence children's eating behaviors. Nutrition education should include the following (Aktaş et. al., 2006a; Anonymous, 2010):

*creating a positive attitude toward food

*encouraging acceptance of a variety of healthy foods

* teaching and promoting an understanding of the relationships between food and health

*providing foods that contain adequate, but not excessive amounts of energy nutrients

*helping children understand their growing bodies and how to take care of themselves through positive health behaviors

* exposing children to a variety of learning experiences about where food comes from and how it can be prepared

*helping children develop sound attitudes and acquire accurate knowledge about food nutrition and health

* fostering the development of healthy food habits in children; improving the knowledge that parents, teachers, administrators and food service personnel have about the principles and practices of nutrition; and developing, promoting, disseminating and/or evaluating nutrition education curricula and material.

There are some important issues that educators should consider in teaching children about nutrition. First, educators should avoid exhibiting behavior that will lead children to dislike food or develop negative behavior towards food, and they should not punish or reward children with food. Prior to teaching children about nutrition, educators should collaborate with parents and teachers and emphasize the main functions of nutrition and help them to understand the messages that will be taught. Since these messages will also be transferred to families through the children, it's imperative that families are prepared in terms of consistency and the reinforcement of students' information. The ideal approach would be to have the educator organize meetings with parents and teachers during the education process to discuss the issues being presented (Merdol, 2012b). 


\section{H. YARDIMCI, F. Ö. ÖRMECİ, A. Ö. ÖZÇELİK, M. S. SÜRÜCÜOĞLU, Y. ÖZDOĞAN}

\section{Abstracts of the Relevant Research Conducted in Turkey}

Aygün (1994) provided five education programs for children between the ages of 5 and 6 , focusing on the benefits of milk, vitamin A, vitamin $\mathrm{C}$ and breakfast and their effect on health, and the relationship between sugary foods and tooth decay. It was found that the children's level of knowledge enjoyed a statistically significant increase after undergoing the educational program. Furthermore, it was observed that although the amount of the leftover food remaining on the plates had not changed significantly, the intake of milk and fruit had increased. It was also determined that when the period of education was shorter and more colored and supported by stories, the program was more influential in terms of increasing the children's knowledge.

Aktaş et al. (2006a), was conducted a study in two stages. The first study was conducted on a total of 94 children (48 of whom were part of the test group and 46 part of the control group; the age ranged from 55 to 80 months) undergoing preschool education at three different schools located in the city center of Konya. All of the participating children came from families who were in the upper socio-economic class. The nutrition education program, which is used by the United States Department of Agriculture, Food and Nutrition Service in their nutrition education research, and the activities used in the program, were applied to the test group children for a period of seven weeks. The Konya-based program (the second stage) was able to be conducted on only 38 students because 10 students were unable to be reached. The students' nutritional knowledge was determined using the "Nutritional Knowledge Test", while their nutritional habits were determined through a "Questionnaire". The students' anthropometric measurements were also taken. Nutrition education activities were integrated into sensory development, language arts, science, dramatic play, art, music, fine and gross motor development and social studies with stories, books, cassettes, videos, cooking, special guests, games, posters, discussions, tasting parties, songs, puzzles, art projects, role playing, skits and puppets by researchers who work as child development and nutrition education specialists. According to the findings obtained from the post-test and the follow-up study, significant increases were observed in the children's height, weight and BMI values $(p<0.01)$. A change was observed in the children's knowledge of how many plates should be consumed from each nutrition group, and according to the results of the dependent t-test, no significant changes were observed in dairy products (t:1.434) and butter and sugar (t:1.00). A change was found in the children's knowledge of nutrition as result of the nutrition education provided.

Aktaş et al. (2006b) investigated the effects of the nutrition education program on the nutritional knowledge and behavior of six-year-old children. The results of the education program showed that there was an increase in the children's knowledge of the food pyramid, food groups and the different types of foods that should be consumed either frequently or rarely, as well as an improvement in their nutritional habits.

In a study carried out by Ünver \&Ünüsan (2005), it was also determined that the nutrition education provided in the preschool period increased the nutritional knowledge level of the children and improved their eating habits.

In another study, Obal1 (2009) aimed to determine the effect of nutrition education administered to children at the age of six by looking at the nutrition education level of children. The research was carried out on kindergarteners at Hurriyet Primary School in the town of Çumra, Konya. A test group and a control group were formed with 15 people each for the application of the 
project. Nutrition knowledge of the food groups was determined by using "The Form for Obtaining Information in Food Groups". A project, titled "The Project for Food Groups", was then designed to raise the levels of understanding children had with regard to food groups. This project was conducted on a test group of 15 children over a period of five weeks. The 15 children who made up the control group were concurrently taught by a teacher using traditional methods that provided the children with limited information. According to the results of the research, it was found that the children in the test group showed positive improvements in their information levels with regard to food groups compared to the children in the control group.

Başkale (2010) carried out a study investigating the development and application of nutrition education aimed at children within the framework of Piaget's theory, and the effect of this education on the nutrition knowledge of children, food consumption frequency, body mass index and arm circumference measurements. Kindergartens representing three socio-economic levels in the city of Izmir were placed randomly in test and control groups in the pre-post test and control designed empirical study. Two hundred and thirty-eight children were included in the study. The kindergarten children in the test group were given a nutrition education based on Piaget's theory. The information levels regarding the nutrition of children and their food consumption frequency were taken prior to the children receiving the education, immediately after receiving the education as well as one year after receiving the education; anthropometric measurements were taken prior to and one year after the kindergartens received the education. It was found that the post-education nutrition knowledge scores of the children in the test group had increased, and positive improvements were observed in the food consumption frequency of the test group compared to the control group. Results following the provision of the education showed an increase in the consumption of milk and dairy products, green leafed vegetables, root vegetables, white meat, fish and fruit, while there was a decrease in the consumption of sugar and ready-made fruit juice. No statistically significant difference was found between the test and control groups after the education in terms of anthropometric measurements.

\section{CONCLUSION}

The personality of a child is largely shaped during the preschool period, and the behavioral habits that are formed during this period will go on to impact adult behavior. Therefore, the eating habits that a child acquires during the preschool period will be brought to bear on their future stages of life and, given that they have adopted healthy habits, be effective in preventing various nutritional problems in the future. Good nutrition and healthy eating habits build a healthy foundation for children. Nutrition education should be provided at every stage of formal and informal education.

\section{REFERENCES}

Ada, (2008). Position of the American Dietetic Association: Nutrition guidance for healthy children ages 2 to 11 years. Journal of The American Dietetic Association,108,10381047.

Aktaş, N., Turan, E., Orcan, M., Bayrak, E., Celikoz, N. \&Aktaş, N. (2006a). The permanence of nutrition education on the knowledge and behaviour of early childhood. In Giannakak1, 


\section{H. YARDIMCI, F. Ö. ÖRMECI, A. Ö. ÖZÇELIK, M. S. SÜRÜCÜOĞLU, Y. ÖZDOĞAN}

M. S., Papanikos, G., Pozios, Y. and Richards, J. K. (eds.). Research on Education. Published by Athens Institute for Education and Research. Athens.

Aktaş, N., Orçan, M., Bayrak, E., Turan, E., Önay, D. \&Aktaş, N. (2006b). Altı yaş çocuklarına uygulanan beslenme eğitimi programının çocukların beslenme konusundaki bilgi ve davranışlarına etkisi. I. Uluslararası Ev Ekonomisi Kongresi, "Sürdürülebilir Gelişme ve Yaşam Kalitesi”. (22-24 Mart 2006, Ankara/Türkiye). Matsa Matbaası, s.241-249, Ankara.

Aktaş, N., Angın, D. E. \&Karakuş, Ö. (2011). The preschool education web-sites and nutritioneducation activities: An assessment by prospective teachers. Scientific Research and Essays. 6(17), p. 3815-3821, Available from: http://www.academicjournals.org/SRE.

Anonymous, (2000). The implementation of nutrition education in preschools in Malaysia. 11p. Paper presented at the Annual Conference of the Australian Association for Research in Education, Sydney.

Anonymous, (2004). Food and nutrition guidelines for pre-school services, Section Three: Important Issues. Health Promotion Unit Department of Health and Children, p:30.

Anonymous, (2008). Eğitimciler için eğitim rehberi beslenme modülleri. T.C. Sağlık Bakanlığı Sağlık Eğitimi Genel Müdürlüğü. İlkay Ofset Matbaacılık, Ankara.

Anonymous, (2010). Nutrition Education. Action Guide for Child Care Nutrition and Physical Activity Policies. Best Practices for Creating a Healthy Child Care Environment. http://www.sde.ct.gov/sde/lib/sde/PDF/DEPS/Student/NutritionEd/CCAG_ActionGuide. pdf

Aygün, Ç. (1994). Beş-altı yaş okul öncesi dönemi çocukları için geliştirilecek beslenme eğitimi programlarının çocukların beslenme ile ilgili bilgi, tutum ve davranışlarına etkisi. Hacettepe Üniversitesi Bilim Uzmanlığı Tezi. Beslenme ve Diyetetik Programı. Ankara.

Barzegari, A., Ebrahimi, M., Azizi, M. \&Ranjbar, K. (2011). A study of nutrition knowledge, attitudes and food habits of college students. World Applied Sciences Journal, 15 (7), 1012-1017.

Başkale, H. (2010). Okul öncesi çocuklara verilen beslenme eğitiminin çocuklarin beslenme bilgisine, davranışlarına ve antropometrik ölçümlerine etkisi. Dokuz Eylül Üniversitesi, Doktora Tezi, İzmir.

Baysal, A. (2014). Beslenme. Ankara. Hatipoğlu Yayınları, Yenilenmiş 15. Baskı.

Contento, I. R. (2008). Nutrition education: linking research, theory, and practice. Asia Pac $J$ Clin Nutr, 17(1), 176-179.

Davidson, J. C. (2012). Nutrition education for early childhood. Wisconsin Department of Public Instruction. http://dpi.wi.gov/fns/index.html

Kilaru. A., Griffiths P. L., Ganapathy, S. \&Shanti, G. (2005). Community-based nutrition education for improving infant growth in Rural Karnataka. Indian Pediatrics, 42,425-432.

Merdol, T. K. (2012a). Okulöncesi dönem eğitimi veren kurumlar için beslenme eğitimi rehberi. Hatiboğlu Yayınları:159, Ankara. 
Merdol, T. K. (2012b). Beslenme eğitimi ve danışmanlı̆̆ı. Sağlık Bakanlığı Yayın No: 726, İkinci Bask1, Ankara.

Mushaphi, L. F. (2011). Impact of a nutrition education programme on the nutritional status of children aged 3 to 5 years and the nutritional practices and knowledge of their caregivers in rural Limpopo Province, South Africa. BSc (Dietetics), Master in Nutrition (University of the North).

Obali, H. (2009). Okulöncesi eğitimi almakta olan altı yas grubu çocuklarına verilen proje yaklaşımıyla beslenme eğitiminin beslenme bilgi düzeyine etkisi. Selçuk Üniversitesi, Yüksek Lisans Tezi, Konya.

Ozcelik, A. O., Surucuoglu, M. S. \& Akan, L. S. (2006). Importance of nutrition education. In Papanicos, G.T. (ed) Issues on Education and Research. Published by Athens Institute for Education and Research. Athens.

Özmert, N. E. (2005). Erken çocukluk gelişiminin desteklenmesi-I: Beslenme. Çocuk Să̆llğl ve Hastalıkları Dergisi, 48, 179-195.

Plum, J. M. (1997). Nutrition knowledge assessment of preschool children. Master of Science in Human Nutrition, Foods and Exercise, Faculty of the Virginia Polytechnic Institute and State University, Blacksburg, Virginia. http://scholar.lib.vt.edu/theses/available/etd101397-204434/unrestricted/etd.pdf

Räsänen, M., Niinikoski, H., Keskinen, S., Tuominen, J.,. SimelL, O., Viikari., J. \&Rönnemaa, T. (2001). Nutrition knowledge and food intake of seven-year-old children in an atherosclerosis prevention Project with onset in infancy:the impact of child-targeted nutrition counselling given to the parents. European Journal of Clinical Nutrition, 55, 260-267.

Stang, J., Story, M. \&Calina, B. (1998). Nutrition education in Minnesota Public Schools: Perceptions and practices of teachers. Journal of Nutrition Education, 30, 396-404.

Stang, J. \& Story, M. (2005). Nutrition education and counseling. Guidelines for Adolescent Nutrition Services.www.epi.umn.edu/let/pubs/img/adol_ch5.pdf

Şanlıer, N. (1999). Ankara köylerindeki 0-6 yaş çocuklarının beslenme durumlarının incelenmesi üzerine bir araştırma. MEB Okul Öncesi Genel Müdürlüğ̈̈ ve GaziÜniversitesi Mesleki Eğitim Fakültesi İş Birliği İle, Ankara.

Ünver, Y. \&Ünüsan, N. (2005). Okulöncesinde beslenme eğitimi üzerine bir araştırma. Selçuk Üniversitesi Sosyal Bilimler Enstitüsü Dergisi, 14, 529-551. 